María Baeza.

\title{
TRES POEMAS
}

I

7 umba la mañana de costado

a la cruz del sur tras de mi casa

y levanta su diamante puro sobre la tierra

aun azul.

El viento desenreda los árboles con sus dedos frescos.

Con la mejilla sobre la almohada te veo dormir; en tu pecho que sube y baja va mi corazón con remo seguro por la viva corriente. No soy ya la virgen; soy tu esposa y el sol rompe su pecho de oro en nuestro cuarto. Reímos. Es el día. 
Mi casa está tendida al sol este verano;

dulce la faena, la hago en un canto.

$M$ is manos preparan para ti $y$ sabias

$y$ ágiles van $y$ vienen.

Por las anchas ventanas entra la luz

cantando con el viento.

Nuestro almuerzo alegre

es un montón de hortalizas, de frutas y de besos.

Asomó el mediodía su rostro ardiente dentro del patio.

En el triángulo de sombra del muro de ladrillos se arrullan dos palomas.

Su arrullo es profundo de amor $y$ de verano.

Cae un chorro de agua y los gorriones picotean, saltan $y$ gritan.

Sola, mis párpados sienten la frescura de la tarde blanca.

Una estrella, dos, tres, mi corazón sale a esperarte $y$ asomado a la esquina no te ve venir.

$M$ is manos se detienen mientras mi cabeza escucha. Cuatro, cinco, seis estrellas, me dice el vidrio de mi ventana. ¿Y él?

El viene caminando hacia mi casa. Dulce calor de mis labios. 
Hundo mi cabeza en tu pecho

y me empino para alcanzar tu boca.

La tarde te me devuelve y somos

un solo corazón que entra a soñar

en el oscuro pensamiento de la noche.

\section{$I I$}

Soñé mi vida, pero esta niña no la soñé.

Soñé con el cardo ardiente de tu amor.

Tu pecho ancho gritaba

a mi pequeño corazón

a través del ambiente delgado de las tardes,

a través del ambiente cobalto de las noches.

Mi cuerpo crecía $y$ se formaba para el hueco de tu corazón. Mis venas esperaban tu latido. Pero el pasto humilde de mi vida no alcanzaba a soñarte, hija mía. $Y$ hoy te tengo aqui, apegada a la fuente de mi pecho; tu manita me palpa $y$ es más ponderada que la dulzura de una flor sobre mi seno. La bellotita fina de tu cabeza morena 
se revuelve en mi pecho

$y$ se lleva mi vida glotonamente.

$Y$ yo me embriago dentro de mí,

me embriago y me pongo a cantar a mi niña.

$Y$ tú nos miras, nos miras

$y$ nos cubres con la mirada tierna

de tus ojos oscuros

que nos sonrien hermosamente.

La voz de la sirena surge

como un gran arrullo

del corazón de paloma

de la mañana.

Mojadas aun de noche

tiemblan entre la niebla

las velas blancas

de las montañas

Echa atrás mi corazón

su capucha de sueños

$y$ surge tu cara morena

$y$ el rostro de flor de mi niña. 
Ambas se asoman

a mi conciencia que parpadea.

Es un foco que enciende y apaga

tu sonrisa de hombre y su sonrisa de flor.

Tiemblan mis manos tendidas

sobre el abismo del mundo.

El caracol de mi alma

se cierra y ensordece.

Blanco y azul el abismo

del mundo está hostil.

Encienden cerca de mi pupila

tu astro ardiente $y$ su estrella pura.

$Y$ mi cuerpo da un salto ágil

$y$ se echa $a$ andar por el mundo

que está nuevo esta mañana. 